\title{
Differential Deficits of Nouns and Verbs in a Generative Naming Task for Individuals with Mild Cognitive Impairment
}

\author{
Sujin Choi ${ }^{\mathrm{a}}$, Jee Eun Sung ${ }^{\mathrm{a}}$, Jee Hyang Jeong ${ }^{\mathrm{b}, \mathrm{c}}$ \\ ${ }^{a}$ Graduate Program in Communication Disorders, Ewha Womans University, Seoul, Korea \\ ${ }^{b}$ Department of Neurology, Ewha Womans University Mokdong Hospital, Seoul, Korea \\ 'Ewha Womans University School of Medicine, Seoul, Korea
}

Correspondence: Jee Eun Sung, PhD Department of Communication Disorders, Ewha Womans University, 52 Ewhayeodae-gil, Seodamun-gu, Seoul 03760, Korea

Tel: $+82-2-3277-2208$

Fax: +82-2-3277-2122

E-mail: jeesung@ewha.ac.kr

Received: October 5, 2019

Revised: November 10, 2019

Accepted: November 14, 2019

This work was supported by the Technology Innovation Program-Industrialized Technology Innovation Project (10077553, Development of Social Robot Intelligence for Social Human-Robot Interaction of Service Robots) funded By the Ministry of Trade, Industry \& Energy (MOTIE, Korea).
Objectives: Individuals with Mild Cognitive Impairment (MCl) have demonstrated word retrieval difficulties. The current study investigated differential deficits in the word retrieval process as a type of the word class (nouns vs. verbs) using generative naming tasks between the $\mathrm{MCl}$ and their control groups.

Methods: Fifteen individual with $\mathrm{MCl}$ and 15 normal controls participated in this study. We administered generative naming tasks of nouns and verbs in both groups. The noun generative naming task consisted of two categories (animate vs. inanimate). Performance on the verb generative naming task was analyzed by the types of verbs.

Results: The $\mathrm{MCl}$ group produced fewer numbers of nouns and verbs on the generation tasks than their controls. Both groups presented significantly lower performance on verbs than nouns. There was no significant difference depending on the animacy in the noun generative naming task. In contrast, there were significant differences in the subtype analyses of verb between the groups, indicating that individuals with $\mathrm{MCl}$ demonstrated significantly lower performance on transitive verbs than their controls, but there was no group difference in intransitive and do-verbs.

Conclusion: The verb generative naming task may serve as a sensitive tool to differentiate the $\mathrm{MCl}$ group from normal aging populations. Furthermore, the more finite analyses of verbs' subtypes can additionally contribute to identifying differential deficits of word retrieval process for individuals with $\mathrm{MCl}$.

Keywords: Mild Cognitive Impairment, Generative naming task, Type of verb, Animacy of noun
2018년 통계청이 실시한 인구 주택 총 조사에 의하면, 우리나라 전체 인구에서 만 65세 이상의 노년 인구는 739만명을 기록하여 전 체 인구의 약 $14.8 \%$ 을 차지하여, 국제 연합(United Nations)이 정한 고령화 사회 기준에 따라, 고령 사회(aged society)에 속한다. 또한 10 년 이내에 노년층 비율이 전체 인구의 $20 \%$ 를 초과하여 초고령 사회(post-aged society)에 진입할 것으로 예상된다. 노년층의 인구 가 빠르게 증가하면서 노후에 대한 인식과 태도에도 변화가 일어나 고 있다. Lee (2009)는 중장년층을 대상으로 노후에 대한 설문 조사
실시 결과, $52 \%$ 가 노후에 대해 걱정을 하고 있으며, 이 중 $40.9 \%$ 는 건강 상실에 대한 두려움을 보고하였다. 이들 중, $10.2 \%$ 는 치매(dementia)와 같은 인지 장애에 대한 걱정과 불안을 호소하였다. 이러 한 결과를 볼 때, 노화와 함께 발생하는 인지적 문제에 대한 고위험 요소들을 조기에 발견하고 중재하는 것은 매우 중요하다.

최근 들어 노화에 따라 발생할 수 있는 대표적인 인지 장애인 치 매와 더불어 경도인지장애(Mild Cognitive Impairment, MCI)에 대 한 관심이 급증하고 있다. $\mathrm{MCI}$ 란, 일상 생활이나 사회 생활을 하는 
데는 큰 문제가 없고 전반적인 인지 기능은 정상으로 유지된다. 하 지만 본인 혹은 보호자가 기억력 저하를 호소하고, 객관적인 검사 에서 동일 연령 및 교육년수에 비해 기억력의 뚜렷한 저하를 보이기 는 하나, 치매가 아닌 상태를 지칭하는 용어이다(Kim, 2003, Petersen, 2004). MCI는 세 가지 아형으로 분류되는데, 기억력에서 두 드러지는 저하를 보이지만, 다른 인지 영역은 보존되는 '기억형 (amnestic) $\mathrm{MCI}$ 와 기억력은 정상이지만 전두엽, 언어, 시공간 영역 중 한 가지 이상에서 현저한 저하를 보이는 '단일 영역(single nonmemory domain) MCI', 마지막으로 기억력, 전두엽, 언어, 시공간 영역 중 2 가지 이상의 영역에서 현저한 저하가 관찰되는 '다중 영역 (multiple domains slightly impairment) MCI'로 나뉜다(Lim, Kim, Baek, Park, \& Kim, 2005). MCI는 알츠하이머병(Alzheimer's Disease, $\mathrm{AD}$ )으로 진행되기도 하는데, $\mathrm{AD}$ 는 치매를 일으키는 가장 대 표적인 퇴행성 뇌 질환으로 점차 기억력과 인지 기능이 손상된다. 특히 기억형 $\mathrm{MCI}$ 는 다른 아형들과 비교하였을 때, $\mathrm{AD}$ 로 진행되는 비율이 높아, 고위험군에 해당한다(Lautenschlager, Riemenschneider, Drzezga, \& Kurz, 2001; Petersen et al., 2001). 그러므로 본 연구에서는 $\mathrm{AD}$ 의 고위험군인 기억형 $\mathrm{MCI}$ 집단을 대상으로 정 상 노화 과정과차이를 보이는 언어학적 요소를 찾고자 하였다.

국외의 경우 정상 노년층이 $\mathrm{AD}$ 로 진단받는 비율이 연간 $1-2 \%$ 에 해당하는 반면, 정상 노년층의 10-15\%는 MCI로 진단되어 발병률 이 $\mathrm{AD}$ 에 비해 거의 10 배 수준으로 높다(Tierney, Yao, Kiss, \& McDowell, 2005). 국내 연구에서는 정상 노년층의 약 24.1-46\%가 MCI 로 진단되어, 전체 인구의 약 $1 / 4$ 의 비율을 차지한다고 하였다(Park, Sung, Kim, \& Lee, 2014; Shin et al., 2011). MCI는 정상 노화와 AD 의 임상학적 중간 단계로(Petersen, 2004), $\mathrm{MCI}$ 의 약 $80 \%$ 가 10 년 이내에 $\mathrm{AD}$ 로 진행되는 등 매우 높은 진행률을 보인다(Petersen et al., 2001). 그러므로 $\mathrm{MCI}$ 를 인지 언어적 양상에서 조기에 감별 진단 하는 것은 매우 중요하다(Östberg, Fernaeus, Hellström, Bogdanović, \& Wahlund, 2005; Petersen, 2004).

$\mathrm{MCI}$ 는 주로 기억력 저하와 함께 단어 산출 능력에 결함을 보인 다(Petersen et al., 1999). 단어를 산출하는 능력은 정상 노년층으로 부터 $\mathrm{MCI}, \mathrm{AD}$ 와 같은 인지 장애를 변별해내는 중요한 요소이다 (Rosen, 1980). 다양한 언어 과제들이 단어 산출 능력을 평가하기 위해서 사용되고 있는데, 대표적으로 대면 이름대기 검사(confrontation naming test), 그림 설명하기 과제(picture description task), 이야기 다시 말하기 과제(story retelling task), 생성이름대기 과제 (generative naming task)등이 있다. 특히, 생성이름대기 과제는 생 성이름대기 능력을 평가할 수 있는 과제로써 전전두엽(prefrontal lobe)의 집행 기능(executive function)과 언어 능력, 의미 기억(se- mantic memory)을 파악할 수 있어(Brucki \& Rocha, 2004), 신경언 어장애 환자군에게 널리 사용된다.

대표적인 생성이름대기 과제에는 두 가지 유형이 존재한다. 첫 번 째 유형은 주어진 시간 내에 특정 범주(동물, 가게물건)에 대한 하위 명사를 최대한 많이 산출해야 하는 의미 범주 유창성 검사(semantic category fluency test)이다. 두 번째 유형은 특정 음소 $(/ \neg /, / O /$, /ㅅ/)로 시작하는 명사를 최대한 산출하는 음소 유창성 검사(phonemic fluency test)로 구성된다. 이러한 두 가지 유형의 과제는 모 두 명사 수준에서의 생성이름대기 능력을 평가하는데 사용된다. 생성이름대기 과제는 검사 소요 시간이 짧고 실시 방법이 간단하 여 집행 기능을 평가하기 위해 신경심리검사에 포함되어 실시되고 있다(Ruff, Light, Parker, \& Levin, 1997). 그 중 의미 범주 유창성 과제는 초기 인지 장애 환자군을 정상 노화 과정으로부터 감별 진 단할 수 있고(Monsch et al., 1992), 노화와 인지 변화에 따른 수행 력 차이를 비교할 수 있어 선별 검사로 자주 사용되고 있다(Baldo \& Shimamura, 1998; Hsieh, Schubert, Hoon, Mioshi, \& Hodges, 2013).

생성이름대기 과제를 이용한 이전의 연구들을 살펴보면, 대부분 의미 범주 유창성 과제 혹은 음소 유창성 과제를 이용한 명사 생성 이름대기가 대부분으로 특정 품사에 국한되어있다는 제한점이 존 재한다. 그러나 정상 노년층 및 신경언어장애군을 대상으로 품사에 따른 생성이름대기 과제를 실시하고 수행력을 비교한 연구 결과, 품사 별 생성이름대기 과제의 수행력이 다르게 나타났다(Berndt, Haendiges, Mitchum, \& Sandson, 1997; Crepaldi et al., 2006; Gleitman, 1994; Lee, 2013; Östberg et al., 2007; Pulvermüller, Mohr, \& Schleichert, 1999). Stokholm, Jørgensen 그리고 Vogel (2013)은 정 상 노년층을 대상으로 명사와 동사 수준에서 생성이름대기 과제 수행력을 비교한 결과, 동사 생성이름대기 과제의 수행력이 유의하 게 낮았다고 하였다. 국내에서도 생성이름대기 과제를 통해 품사에 따른 차이를 비교한 시도가 이루어졌는데, Lee (2013)는 정상 노년 층을 대상으로 명사 및 동작 동사 생성이름대기 과제를 실시하였 는데, 그 결과 정상 노년층은 동작 동사를 산출하는데 어려움을 보 인다고 하였다. 그러나 이러한 결과는 정상 노년층만을 대상으로 하고 있기 때문에, 신경언어장애 집단에게 그 결과를 일반화하기에 는 어려움이 있다. 신경언어장애 집단을 대상으로 한 품사 별 생성 이름대기 수행력 비교는 주로 실어증 환자들을 대상으로 이루어졌 는데, 실어증 환자 집단에서도 명사에 비해 동사를 주어진 시간 내 에 산출하는 데 결함을 보인다고 보고하였다(Berndt et al., 1997; Crepaldi et al., 2006; Pulvermüller et al., 1999).

동사 산출이 명사에 비해 어려운 이유는 바라보는 언어학적 관 
점에 따라 여러 견해가 존재한다. 첫째, 의미론(semantic)적 측면에 서 두 품사를 비교해보면, 명사와 동사는 빈도(frequency), 그림으 로 표현될 수 있는 특성(imageability) 등이 다르기 때문에 산출하 는 데 차이를 보일 수 있다(Druks, 2002; Luzzatti \& Chierchia, 2002; Sung, DeDe, \& Lee, 2016). 다시 말해, 명사는 참조하는 대상이 명 확하고 구체적이며 빈도가 높기 때문에 동사에 비해 산출하기 쉬 운 것이다. 또한 동사가 가진 의미의 정도에 따라 동사 내에서도 단 어 산출에 차이를 보일 수 있다. Barde, Schwartz와 Boronat (2006) 은 실문법증(agrammatism)을 가진 실어증 환자를 대상으로 의미 적 요소가 많은 중동사(semantically heavy verb)와 의미적 요소가 적은 경동사(semantically light verb)로 나누어 비교하였다. 그 결 과, 경동사에 비해 중동사를 더 쉽게 산출하였는데, 중동사는 포함 된 의미적 요소가 많기 때문에 통사적 정보에 덜 의존하지만, 경동 사는 의미적 요소의 제한으로 인하여 통사적 정보에 더 의존하게 된다. 하지만 실문법증 환자는 통사적 정보를 입력하고 처리하는데 결함을 보이기 때문에 상대적으로 경동사 산출에 제한을 보이는 것이라고 해석하였다.

둘째, 통사적(syntactic) 측면에서 명사와 동사를 비교하면, 동사 는 명사에 비해 통사적으로 복잡한 구조를 가진다. 동사는 그 의미 를 완성하기 위해 문장 내에서 필요한 언어적 요소인 논항을 가진 논항 구조(argument structure)로 이루어져있다. 국립국어원 표준 국어대사전에 따르면 자동사(intransitive verb)는 동사가 나타내는 동작이나 작용이 주어에만 영향을 미치는 데, 예를 들어 '꽃이 피 다', '해가 솟다'에서 '피다', '솟다'에 해당하는 동사로 1 개의 주격 논 항이 필요한 1항 동사이다. 그에 반해, 타동사(transitive verb)는 주 격 논항과 함께 동작의 대상이 되는 목적어가 필요한 동사로 '밥을 먹다', '노래를 부르다'에서 '먹다', '부르다'와 같은 동사로 2항 동사 이고, 3항 동사는 2항 동사에 여격 논항이 추가되는 형태이다(Sung $\& \mathrm{Kwak}, 2012)$. 즉, 타동사는 자동사에 비해 필요한 논항의 수가 많 기 때문에 통사적으로 더 복잡한 형태를 가지고 있다(Druks, 2002; Sung \& Kwak, 2012).

이처럼 동사는 통사적 구조에 따라 다양한 유형으로 분류되는 데, 논항 구조의 복잡성(complexity)에 따라 정상 노년층 및 신경언 어장애 집단에서 동사 산출 수행력은 달라진다(Druks, 2002; Kim \& Thompson, 2000; Sung \& Kwak, 2012). Sung과 Kwak (2012)은 동사 이름대기 과제를 통해 청년층 집단과 노년층 집단의 수행력을 비교하였는데, 그 결과 노년층 집단이 청년층 집단에 비해 논항 구 조가 복잡한 동사를 산출하는데 어려움을 보인다고 하였다. 또한 실어증 환자 집단을 대상으로 한 연구들에서도 논항의 수가 증가함 에 따라 동사를 산출하는데 결함을 보인다고 하였다(Druks, 2002;
Kim \& Thompson, 2000; Sung, 2016). Sung (2016)은 실어증 환자 와 정상 노년층 집단을 대상으로 대면이름대기 과제를 통해 동사의 논항에 따른 수행력의 차이를 비교하였다. 그 결과, 실어증 환자 집 단은 1항 동사에 비해 3항 동사를 산출하는데 더 어려움을 보여 논 항이 증가함에 따라 동사 산출에 어려움이 생긴다는 기존 연구 결 과와 일치하였다. 그러나 그 외의 동사에서는 논항 수에 따른 유의 한 차이를 보이지 않았는데, Sung은 이를 'S (Subject) $+\mathrm{O}$ (object) $+\mathrm{V}$ (verb)'의 구조를 가진 한국어 특징 때문이라고 하였다. 1항과 2 항 동사의 수행력을 비교해보면, 1 항 동사는 필요한 논항이 주격으로 한 개이지만, 2 항 동사는 주격과 대격이 필요한 동사이다. 하지만 주어가 자주 생략되는 한국어 특성 때문에, 2항 동사에서 주어가 생략되어, 1 항 동사처럼 여겨지기 때문에 차이를 보이지 않을 수 있 다고 하였다. 또한 2항과 3항을 비교해보았을 때, 2항과 3항 동사의 문장 내 산출 형태를 살펴보면 필요한 논항 외에 부사구가 추가되 어 문장이 길어지는 특징을 보였는데, 이러한 영향으로 인해 2항과 3 항에서 유의한 차이를 보이지 않았다고 해석하였다. 이처럼 동사 가 마지막에 오는 한국어에서는 동사의 유형에 따라 수행력의 차이 를 보이기 때문에 동사를 더 다양한 측면에서 분석할 필요가 있다.

동사 산출 능력에 대한 중요성이 증가함에 따라, $\mathrm{MCI}$ 를 대상으 로 명사 및 동사 산출 능력을 평가하는 연구들이 이루어지고 있다 (Alegret et al., 2018; Bird, Ralph, Patterson, \& Hodges, 2000; Bushell, \& Martin, 1997; Cappa et al., 1998; Druks et al., 2006; Östberg et al.,2005). Östberg 등(2005)은 주관적 인지 장애(Subjective Cognitive Impairment), MCI, AD 집단을 대상으로 명사 및 동사 생성 이름대기 과제를 실시하고 그 수행력을 비교하였다. 그 결과, 세 집 단 모두 명사에 비해 동사 생성이름대기 능력에 어려움을 보이는 것으로 나타나 기존 연구들과 동일한 결과를 나타냈다. 또한 그들 은 동사를 이용한 생성이름대기 과제가 명사 생성이름대기 과제에 비해 $\mathrm{MCI}$ 집단을 민감하게 감별해줄 수 있는 중요한 도구라고 하 였다. Alegret 등(2018)은 동사 생성이름대기 과제를 통해 정상 노년 층, $\mathrm{MCI}, \mathrm{AD}$ 의 수행력 차이를 비교하였는데, 그 결과 정상 노년층 에 비해 $\mathrm{MCI}$ 집단이 동사 생성이름대기 과제에서 낮은 수행력을 보였고, $\mathrm{MCI}$ 에 비해서는 $\mathrm{AD}$ 의 수행력이 낮았다. 또한 그들은 동사 생성이름대기 과제와 정상 노화에서 $\mathrm{MCI}$ 로 진행되는 과정 및 $\mathrm{MCI}$ 에서 $\mathrm{AD}$ 로 진행되는 과정 사이의 매우 높은 연관성을 제시하며, 동사 생성이름대기 과제는 정상 노년층으로부터 $\mathrm{MCI}$ 를 변별할 수 있을 뿐만 아니라, $\mathrm{MCI}$ 에서 $\mathrm{AD}$ 로 전이되는 과정을 예측할 수 있는 중요한 과제라고 하였다. 즉, 명사 뿐 아니라 동사는 노화와 관련된 언어 수행력의 감소를 예측하는 데 매우 중요한 품사이고, $\mathrm{MCI}$ 를 조기 진단하는 데 민감한 지표이므로(Kim, 2017; Östberg et al., 
2005; Ramsay, nicholas, Au, Obler, \& Albert, 1999), 명사와 함께 필 수적으로 평가되어야 한다. 국내에서도 명사와 동사 산출력을 직접 적으로 비교하는 연구가 보고되기는 하나, 실어증(Hyun, Kim, Shin, \& Seo, 2003; Kim, Park, Kim, Hwang, 2004)이나 정상 노화 과정(Lee, 2013)에서 나타나는 단어 산출의 저하를 밝히는 데 초점 이 맞춰져 있다.

최근 들어 국내에서 생성이름대기 과제를 이용하여 신경언어장 애군을 감별하려는 시도들이 다양하게 이루어지고 있으나, 모두 명 사 수준의 생성이름대기 과제에 국한되어 있다(Choi, 2010; Choi, 2012; Choi, Lee, Choi \& Lee, 2017). 또한 MCI를 대상으로 명사와 동사의 수행력을 비교하는 연구가 발표되었으나, 대면이름대기 과 제를 통해수행력을 비교하는 방법을 사용하였고(Choi, Sung, Jeong, $\&$ Kwag, 2013), 이 또한 매우 제한적이다. 앞서 언급한 선행 연구들 을 종합해보면, 생성이름대기 과제는 노화 과정의 비정상적인 인지 저하를 감별해낼 수 있고, 특히 동사를 이용한 생성이름대기 과제 는 명사에 비해 전두엽(frontal lobe)의 기능을 더 민감하게 측정할 수 있기 때문에(Woods et al., 2005), 정상 노년층으로부터 MCI 집 단을 감별해줄 수 있는 중요한 과제일 수 있다. 하지만 아쉽게도 국 내에서 생성이름대기 과제를 이용하여 정상과 $\mathrm{MCI}$ 집단의 명사와 동사 산출을 비교한 연구는 없다. 그러므로 본 연구에서는 $\mathrm{MCI}$ 를 대상으로 품사(명사 vs. 동사)에 따른 생성이름대기 과제를 실시하 여 두 집단 간차이가 어떠한지 살펴보고자 하였다.

기존에 수행된 명사 생성이름대기 과제들을 살펴보면, 생물성 (animacy) 유무에 따른 수행력 차이를 비교하였는데 그 결과는 매 우 분분하다. Cunje, Molloy, Standish와 Lewis (2007)는 MCI 집단 과 정상 노년층 집단이 생물성 및 무생물성 범주에서 유의한 차이 를 보이지 않는다고 하였고, Price 등(2012)은 두 집단 모두 무생물 성 범주에서 높은 수행력을 보인다고 하였다. 또한 $\mathrm{AD}$ 집단의 경 우, 생물성 및 무생물성 범주가 처리되는 뇌의 기전에서도 차이를 보인다(Choi, 2008; Gainotti, 2000). 그러므로 본 연구에서는 보다 세부적으로 명사 생성이름대기 과제를 생물성 유무에 따라 분류 하고 각 집단간 차이를 살펴보고자 하였다. 그리고 동사 생성이름 대기 과제는 각 집단의 대상자들이 산출한 동사의 유형을 복잡성 에 따라 자동사와 타동사로 분류하여 비교하였다. 또한 한국어에 서는 명사(예: 청소)와 접미사 '하다’가 결합하여 동사(예: 청소하 다)로 사용되는 용언의 형태가 존재하는데, 본 연구에서는 이를 ‘-하다' 동사(do-verb)라고 지칭하고 분류 유형에 추가하였다. 본 연 구의 연구 질문은 다음과 같다.

첫째, 품사(명사 vs. 동사)에 따라 MCI 집단과 정상 노년층 집단 의 생성이름대기 과제 수행력에 유의한 차이가 있는가?
둘째, 명사의 생물성 유무(생물성 vs. 무생물성) 에 따라 MCI 집 단과 정상 노년층 집단의 생성이름대기 과제 수행력에 유의한 차이 가 있는가?

셋째, 동사의 유형(자동사, 타동사, ‘-하다' 동사)에 따라 MCI 집 단과 정상 노년층 집단의 생성이름대기 과제 수행력에 유의한 차이 가 있는가?

\section{연구방법}

\section{연구 대상}

본 연구에 참여한 대상자는 서울 및 경기도에 거주하는 $\mathrm{MCI}$ 집 단 15 명(남자 3 명, 여자 12 명) 과 정상 노년층 집단 15 명(남자 4 명, 여 자 11 명)으로 총 30 명이다. 정상 노년층 집단의 연령은 노인복지법 에서 정한 만 65 세 이상을 기준으로 선정하였다.

\section{$\mathrm{MCl}$ 선정 기준}

$\mathrm{MCI}$ 집단은 신경심리학적 검사 등을 통해 신경과 전문의에 의해 amnestic MCI로 진단되었다. 또한 Petersen (2004)의 진단 기준에 근거하여 1) 환자 또는 보호자에 의한 주관적 기억력 저하 호소, 2) 서울신경심리검사(Seoul Neuropsychological Screening Battery, 이하 SNSB-II; Kang, Jang, \& Na, 2012)의 하위 인지 기능 검사 중 2 가지 이상의 영역이 $16 \%$ ile이하로 객관적인 기억력 장애가 있는 자, 3) 한국판 간이 정신상태 진단 검사(Korean-Mini Mental State Examination; 이하 K-MMSE, Kang, 2006) 결과, 연령 및 교육년수 대 비 $16 \%$ ile 이상의 정상 범위에 속하는 자, 4) 한국형 도구적 일상생 활 활동(Korean-Instrumental Activities of Daily Living, K-IADL; Won et al., 2002) 점수가 .43 미만으로 일상생활에 어려움이 없는 자, 5) 임상치매척도(Clinical Dementia Rating, CDR; Hughes et al., 1982)가.5로 치매로 분류되지 않은 자, 6) 단축형 노인우울척도 (Short version of the Geriatric Depression Scale; 이하, SGDS; Jung, Kwak, Joe, \& Lee, 1997)의 점수가 8 미만으로 기억력 장애가 우울증과 같 은 정신과학적 원인에서 기인하지 않고, 그 밖에 신경학적 병력이 없는 자를 대상으로 하였다.

또한 MCI 집단은 미국 국립노화 연구소(National Institute on Aging-Alzheimer's Association; NIA-AA)에서 정한 $\mathrm{MCI}$ 의 기준 (Jack et al., 2018)을 모두 충족하였다.

\section{정상 노년층 선정 기준}

정상 노년층 집단은 1) K-MMSE 점수가 연령 및 교육년수 대비 $16 \%$ ile 이상의 정상 범위에 속하고, 2) SNSB의 하위 검사인 서울 구 
Table 1. Demographic information of $\mathrm{MCl}$ and NEA individuals

\begin{tabular}{lcccc}
\hline & $\mathrm{MCl}(\mathrm{N}=15)$ & $\mathrm{NEA}(\mathrm{N}=15)$ & $t$ & $p$ \\
\hline Sex & & & & \\
$\quad$ Male & 3 & 4 & - & - \\
$\quad$ Female & 12 & 11 & & \\
Age (yr) & $72.47 \pm 5.03(64-81)$ & $73.07 \pm 5.24(67-83)$ & .32 & .751 \\
Education (yr) & $5.5 \pm 5.2(0.5-16)$ & $6.7 \pm 5.03(0.5-16)$ & .643 & .526 \\
\hline
\end{tabular}

Values are presented as mean $\pm \mathrm{SD}$ (range).

$\mathrm{MCl}=$ Mild Cognitive Impairment; NEA= Normal Elderly Adult.

어 학습 검사(Seoul Verbal Learning Test) 점수가 연령 및 교육년수 대비 $16 \%$ ile 이상의 정상 범위에 속하는 자, 3) K-IADL 점수가 .43 미만으로 정상 범위에 속하고, 4) SGDS의 점수가 8 미만으로 정상 범위에 속하는 자, 5) 건강선별설문지(Health Screening Questionnaire, Christensen, multhaup, Nordstrom, \& Voss, 1991) 보고 결 과, 의학적, 신경학적 병력이 없는 자를 대상으로 하였다.

두 집단의 연령 및 교육년수에서 유의한 차이가 있는 지를 검증 하기 위해 독립표본 $t$ 검정(independent $t$-test)을 유의수준 .05에서 실시한 결과, 연령 $\left(t_{(28)}=.32, p=.751\right)$ 및 교육년수 $\left(t_{(28)}=.643, p=.526\right)$ 에는 통계적으로 유의한 차이가 없었다. 두 집단의 기술 통계 정보는 Table 1에 제시하였고, 신경심리검사 결과는 Table 2에 제시하였다.

\section{연구 자극 및 절차}

정상 노년층 집단과 $\mathrm{MCI}$ 집단의 명사 및 동사에서 생성이름대기 능력을 비교하기 위해 품사에 따른 생성이름대기 과제를 실시하였 다. 대상자의 모든 반응은 녹음한 후, 전사하여 분석하였다.

\section{명사 생성이름대기 과제}

명사 수준에서 생성이름대기 능력을 평가하기 위해 SNSB의 하 위 검사 중 통제 단어 연상 검사(Controlled Oral Word Association Test; Kang, Chin, Na, Lee, \& Park, 2000)의 의미 범주 유창성 검사 를 실시하였다. 의미 범주 유창성 검사는 크게 생물성 유무에 따라 생물성 범주인 '동물'과 무생물성 범주인 '가게 물건'으로 구성되어 있고, 검사 지침에 따라 '동물'을 먼저 시행하고 '가게 물건'을 실시 하였다. 연구자는 대상자에게 제한 시간 1 분 내에 “제가 '시작’하면 동물(혹은 가게 물건)의 이름을 가능하면 많이 말씀해주십시오." 의 지시와 함께 검사를 실시하였다. 대상자에게 추가적으로 범주 에 대한 단서를 제시하지 않기 위해, '더 생각나는 것이 있나요?'의 지시를 추가로 할 수는 있으나, 범주에 대한 재언급은 하지 않는 것 을 원칙으로 하였다. 채점은 반응 1 개에 1 점씩 부여하여 범주 별로 총점을 계산하였다. 단, 대상자의 반응 중 중복된 반응과 목표 범주
Table 2. Screening results from neuropsychological tests

\begin{tabular}{lcc}
\hline & $\mathrm{MCl}(\mathrm{N}=15)$ & $\mathrm{NEA}(\mathrm{N}=15)$ \\
\hline K-MMSE & $23.9 \pm 3.43(19-30)$ & $28.67 \pm 1.18(26-30)$ \\
SVLT-immediate & $15.87 \pm 7.0(5-29)$ & $19.4 \pm 5.89(7-28)$ \\
SVLT-delayed & $3.8 \pm 3.47(0-10)$ & $5.53 \pm 3.2(0-10)$ \\
Digit span-forward & $3.73 \pm 1.94(1-8)$ & $5.13 \pm 1.30(3-7)$ \\
Digit span-backward & $3.13 \pm 1.88(1-9)$ & $4.27 \pm 1.44(1-7)$ \\
\hline
\end{tabular}

Values are presented as mean $\pm S D$ (range).

$\mathrm{MCl}=$ Mild Cognitive Impairment; NEA=Normal Elderly Adult; K-MMSE=KoreanMini Mental State Examination (Kang, 2006); SVLT = Seoul Verbal Learning Test.

에 속하지 않은 명사는 오반응으로 처리하였으며, 상위 개념의 단 어와 구체적인 하위 개념의 단어를 중복한 경우(예: 과일, 사과, 포 도, 바나나)에는 상위 개념 단어(과일)는 점수에서 제외하고 하위 개념의 단어(사과, 포도, 바나나)만을 점수에 반영하였다.

\section{동사 생성이름대기 과제}

동사 수준에서 생성이름대기 능력을 평가하기 위해 Woods 등 (2005)의 검사 방법을 기반으로 동사 생성이름대기 과제를 실시하 였다. 연구자는 대상자에게 3 개의 연습 문항(쓸다, 마시다, 주다)을 그림 자극과 함께 제시하여 동사의 개념에 대해 충분히 이해시킨 후, 검사를 실시하였다. '지금부터 행동이나 움직임에 관한 단어를 가능하면 많이 말씀해주세요'의 지시와 함께 검사가 진행되었고, 제한 시간은 1 분으로 명사 생성이름대기 과제와 동일하였다. 대상 자가 산출한 동사는 세부적으로 자동사, 타동사, '-하다' 동사의 세 가지 유형으로 분류하고, 각각 1 점씩 부여하여 총점을 산출하였다.

\section{자료의 통계적 처리 및 종속 변수 설정}

본 연구에서는 정상 노년층 집단과 $\mathrm{MCI}$ 집단을 대상으로 명사 및 동사 생성이름대기 과제의 수행력 차이를 검증하기 위하여 PASW (PASW statistics 25.0, SPSS Inc.)를 사용하여 통계 분석을 실시하 였다. 연구 질문에 따라 다음과 같은 분석 방법을 사용하여 통계적 검증을 실시하였다.

연구질문 1: 품사에 따른 집단 간 생성이름대기 과제 수행력의 차 이를 보기 위하여 이원 혼합 분산분석(two-way mixed analysis of variance)를 실시하였다. 명사 생성이름대기 과제는 '동물'과 '가게 물건'의 두 가지 범주가 각각 1 분씩 따로 수행되었기 때문에, 두 범 주의 평균을 종속 변수로 설정하였다. 동사 생성이름대기 과제는 1 분 동안 산출한 동사의 총 개수를 총점으로 하여 종속 변수로 설정 하였다.

연구질문 2: 명사 범주의 생물성 유무에 따른 생성이름대기 과제 의 집단 간 차이를 비교하기 위하여 이원 혼합 분산분석(two-way 
mixed analysis of variance)을 실시하였다. 명사 생성이름대기 과제 는 범주라는 하나의 요인(factor)에 생물성 유무에 따라 두 가지 수 준(level)이 존재하기 때문에, 하나의 독립 변수로 설정하고, (1) 생 물성 범주(동물) 총점과, (2) 무생물성 범주(가게 물건) 총점을 종 속 변수로 설정하여 통계적 검증을 실시하였다.

연구질문 3: 동사 생성이름대기 과제는 1 분 동안 시행한 한 개의 과제를 Ad-hoc 분석에 따라 추가적으로 세 가지 동사 유형(자동사, 타동사, '-하다' 동사)에 따라 분석하였으므로, 각 동사의 유형을 독 립 변수로 설정할 수 없어, 일원 분산분석(one-way analysis of variance)을 이용하여 통계적 검증을 실시하였다. 이 때, 1 분 동안 산출 한 전체 동사중 (1) 자동사 비율, (2) 타동사 비율, (3) '-하다' 동사비 율을 종속 변수로 설정하였다.

\section{연구결과}

\section{품사에 따른 생성이름대기 과제 수행력}

명사 및 동사 생성이름대기 과제에서 집단 간 수행력의 차이를 비교하기 위하여 이원 혼합 분산분석을 유의수준 .05에서 실시하 였다. 그 결과, 집단 간 품사에 따른 상호작용(interaction)은 통계적 으로 유의하지 않았다 $\left(F_{(1,28)}=.883, p=.355\right.$, partial $\left.\eta^{2}=.031\right)$. 그러 나 집단 간주 효과 (main effect)가 통계적으로 유의하였는데 $\left(F_{(1,28)}=\right.$ $9.878, p=.004$, partial $\left.\eta^{2}=.261\right), \mathrm{MCI}$ 집단이 정상 노년층 집단에 비해 생성이름대기 과제에서 저조한 수행력을 보였다. 또한 품사 유 형에 따른주 효과가 통계적으로 유의하였다 $\left(F_{(1,28)}=91.229, p=.000\right.$, partial $\left.\eta^{2}=.765\right)$. 다시 말해 두 집단 모두 동사 생성이름대기 과제 의 수행력이 명사 생성이름대기 수행력에 비해 저조하였다. 두 집단 간 품사에 따른 생성이름대기 과제 수행력 차이는 Figure 1에 제시 하였다.

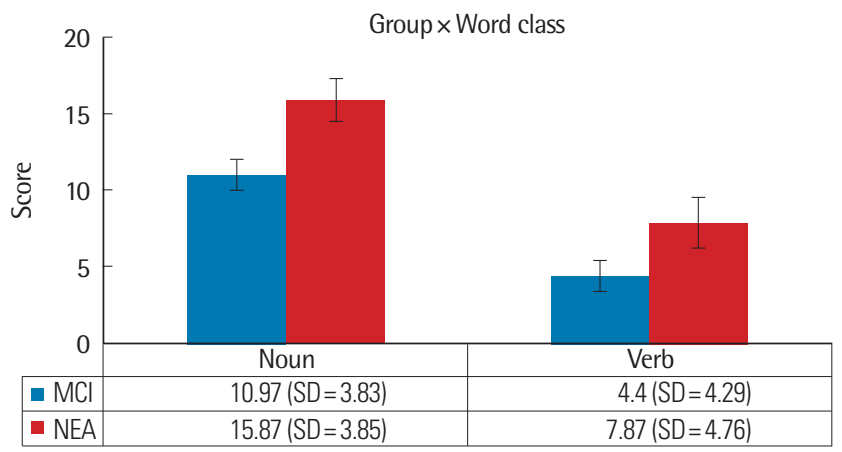

Figure 1. Performance on a word fluency tasks according to task type (noun vs. verb) between $\mathrm{MCl}$ and NEA.

$\mathrm{MCl}=$ Mild Cognitive Impairment; NEA = Normal Elderly Adults

\section{명사의 생물성 유무에 따른 집단 간 생성이름대기 과제 수행력}

명사 생성이름대기 과제에서 두 집단 간 범주(생물성, 무생물성) 에 따른수행력 차이를 비교하기 위하여 이원 혼합 분산분석을 유의 수준 .05에서 실시하였다. 그 결과, 집단 간 범주에 따른 상호작용은 통계적으로 유의하지 않았다 $\left(F_{(1,28)}=18.15, p=.131\right.$, partial $\left.\eta^{2}=.08\right)$. 그러나 집단 간 주 효과가 통계적으로 유의하였는데 $\left(F_{(1,28)}=12.209\right.$, $p=.002$, partial $\left.\eta^{2}=.304\right), \mathrm{MCI}$ 집단이 정상 노년층 집단에 비해 명사 생성이름대기 과제 수행력이 낮았다. 범주에 따른 주 효과는

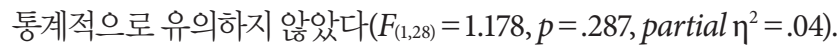
두 집단 간 범주에 따른 생성이름대기 과제 수행력 차이는 Figure 2 에 제시하였다.

\section{동사의 유형에 따른 집단 간 생성이름대기 과제 수행력}

동사 생성이름대기 과제에서 동사의 유형에 따른 집단 간 수행력 을 비교하기 일원 분산분석을 유의수준 .05에서 실시하였다. 그 결 과, 타동사에서 두 집단 간 수행력 차이가 통계적으로 유의하였다 $\left(F_{(1,28)}=6.088, p=.02\right)$. 즉, $\mathrm{MCI}$ 집단이 정상 노년층 집단에 비해 타 동사를 유의하게 적게 산출하는 것으로 나타났다. 그러나 두 집단 간 자동사의 산출 능력 $\left(F_{(1,28)}=.083, p=.776\right)$ 과 '하다' 동사의 산출

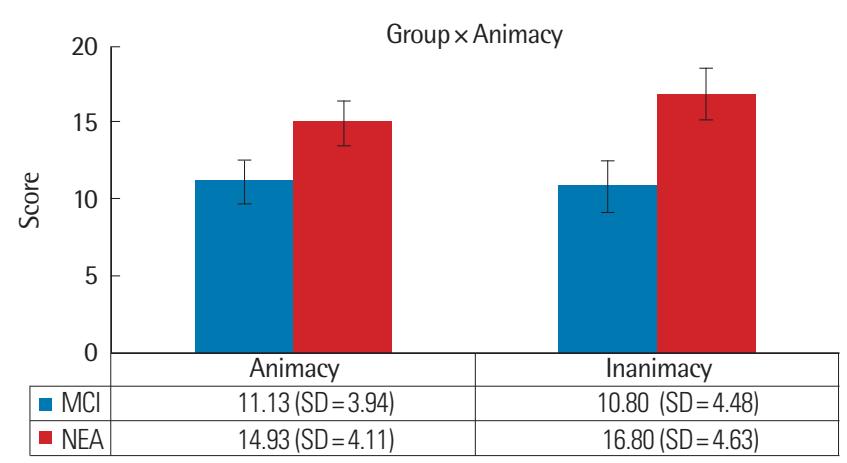

Figure 2. Performance on a word fluency tasks according to category (animacy vs. inanimacy) between $\mathrm{MCl}$ and NEA.

$\mathrm{MCl}=$ Mild Cognitive Impairment; NEA= Normal Elderly Adults.

Table 3. Descriptive information for the type of verbs

\begin{tabular}{lccrl}
\hline & $\mathrm{MCl}(\mathrm{N}=15)$ & $\mathrm{NEA}(\mathrm{N}=15)$ & $F$ & $p$ \\
\hline Total score & $4.40(4.29)$ & $7.87(4.76)$ & 4.387 & $.045^{*}$ \\
Intransitive verb & $.34(.33)$ & $.37(.26)$ & .083 & .776 \\
Transitive verb & $.21(.23)$ & $.46(.31)$ & 6.088 & $.020^{*}$ \\
Do-verb & $.19(.21)$ & $.18(.26)$ & .017 & .897 \\
\hline
\end{tabular}

Values are presented as mean (SD).

$\mathrm{MCl}=$ Mild Cognitive Impairment; NEA= Normal Elderly Adults. ${ }^{*} p<.05$. 


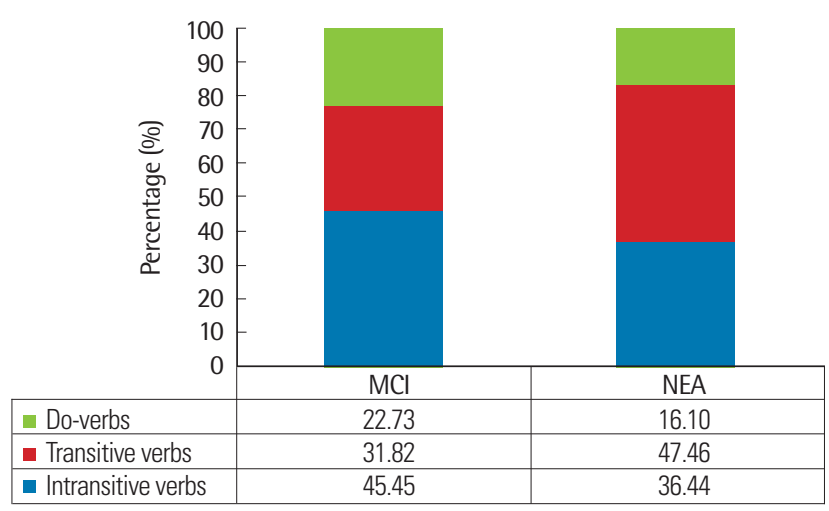

Figure 3. Ratio of each verb type in a verb fluency task in both groups. $\mathrm{MCl}=$ Mild Cognitive Impairment; NEA = Normal Elderly Adults.

능력 $\left(F_{(1,28)}=.017, p=.897\right)$ 에서는 유의한 차이를 보이지 않았다. 동 사 유형에 따른 생성이름대기 과제의 기술통계 정보는 Table 3에 제 시하였다. 또한 두 집단 간 동사 유형에 따른 산출 비율은 Figure 3 에 제시하였다.

\section{논의 및 결론}

생성이름대기 과제는 제한된 시간 내에 특정 단어를 산출하는 생성이름대기 능력을 평가하는 과제로 전두엽의 집행 기능, 언어 기능 및 의미 기억 등 인지 언어 관련 기제와 함께 주의집중력, 전반 적 모니터링 능력 등을 비교적 짧은 시간 내에 파악할 수 있어 신경 언어장애군을 대상으로 전 세계에 걸쳐 사용되고 있다. 국외에서 는 명사를 이용한 생성이름대기 과제 뿐만 아니라, 동사 생성이름 대기 과제를 통해, $\mathrm{MCI}$ 집단을 정상 노화 과정으로부터 감별해내 려는 연구들이 활발하게 이루어지고 있다(Alegret et al., 2018; Bird et al., 2000; Bushell \& Martin, 1997; Cappa et al., 1998; Druks et al., 2006; Östberg et al.,2005). 하지만 국내에서는 MCI 집단을 대 상으로 명사 및 동사 생성이름대기 과제를 실시하여 수행력 차이 를 비교한 연구는 없다. 그러므로 본 연구에서는 정상 노년층 집단 과 $\mathrm{MCI}$ 집단에게 명사 및 동사 생성이름대기 과제를 실시하고 집 단 간 수행력 차이를 비교하고, $\mathrm{MCI}$ 집단을 정상 노년층 집단으로 부터 감별할 수 있는 언어적 요소를 확인하고자 하였다.

첫 번째로 품사(명사 vs. 동사)에 따라 정상 노년층 집단과 $\mathrm{MCI}$ 집단의 생성이름대기 과제의 수행력을 비교하였다. 그 결과, 두 집 단 간 주 효과가 통계적으로 유의하였는데, $\mathrm{MCI}$ 집단이 정상 노년 층 집단에 비해 제한 시간 내에 명사와 동사를 산출하는 데 더 어려 움을 보이는 것으로 나타났다. 이는 $\mathrm{MCI}$ 집단이 정상 노년층에 비 해 단어를 산출하는 데 결함을 보인다는 선행 연구와 일치한다(Clark et al., 2014; Petersen et al., 1999). 그러나 K-MMSE에서 MCI 집단 이 정상 규준에 속하였음에도 불구하고, 정상 노년층과 통계적으 로 유의한 차이를 보여 전반적인 인지 기능이 저하된 것으로 나타 났다. 이러한 집단 간 인지 기능의 차이가 생성이름대기 과제의 수 행력에 영향을 미쳤을 가능성을 배제할 수 없다. 하지만 동사의 유 형 중 타동사에서만 $\mathrm{MCI}$ 집단이 결함을 보인다는 것을 확인할 수 있었다. 즉, 이러한 결과는 전반적인 생성이름대기의 수행력 보다는 품사에 따라 분류하고, 동사의 경우 문법적 요소로 나누어 살펴보 는 것이 $\mathrm{MCI}$ 집단의 생성이름대기 능력을 정상으로부터 감별할 수 있다는 점을 시사한다.

또한 품사 유형에 따른 주 효과가 통계적으로 유의하였는데, 두 집단 모두 명사보다 동사산출에서 어려움을 보였다. 이러한 결과는 정상 노년층 및 $\mathrm{MCI}$ 집단이 명사보다 동사를 산출하는 데 어려움 을 보인다는 기존의 선행 연구와 일치한다(Clark et al., 2014; Östberg et al., 2005; Stokholm et al., 2013). 명사는 참조하는 대상이 명 확하고 구체적이며, 빈도가 높기 때문에 동사에 비해 쉬울 수 있다. 하지만 동사는 명사에 비해 추상적이고, 연속적인 행동이나 움직 임을 나타내기 때문에 이미지화하기 어렵다. 그리고 명사는 문장 내에서 다른 언어적 성분 없이 홀로 쓰일 수 있으나, 동사는 대부분 주어 또는 목적어와 같은 다양한 언어적 성분이 결합되어 사용되 는 특성을 가지고 있다. 또한 동사는 어간에 시제(예: 먹었다, 먹고 있다. 먹을 것이다), 피동형(예: 먹히다), 사동형(예: 먹이다)의 문장 형태에 따라 다양한 어미가 결합하여 여러 가지 형태로 활용되기 때문에 명사보다 복잡하다. 실제로 본 연구에 참여한 두 집단의 품 사 별 산출 형태를 살펴보면, 명사는 단독으로 산출되었으나(예: 코 끼리, 사자, 쥐), 동사는 문장 형태로 산출되는 경향을 보였다(예: 철 수가 밥을 먹네, 학교에 갔다). 이는 동사가 마지막에 위치하는 한국 어 특성 상, 동사 이전에 오는 의미 및 통사적 요소가 먼저 활성화되 고, 이후에 동사 재인의 과정을 거치기 때문이라고 할 수 있다. 이처 럼 동사 생성이름대기 과제에서 산출된 동사의 유형 분석을 통해, 명사 생성이름대기 과제에서는 확인할 수 없었던 통사적 및 형태적 요소에 대한 정보를 확인할 수 있다는 점에서 의미 있는 결과로 해 석된다.

두 번째로 본 연구에서는 정상 노년층 집단과 $\mathrm{MCI}$ 집단을 대상 으로 명사 생성이름대기 과제를 실시하고, 생물성 유무에 따라 두 가지 범주(생물성 Vs. 무생물성)로 나누어 비교하였다. 그 결과, 집 단 간 주 효과가 유의하였는데, $\mathrm{MCI}$ 집단이 정상 노년층 집단에 비 해 명사 생성이름대기 과제 수행력이 유의하게 저하된 것으로 나타 나 기존의 선행 연구와 일치하였다(Choi, 2011; Östberg et al., 2005; Price et al., 2012). 그러나 범주 간 주 효과는 통계적으로 유의하지 
않았다. 이러한 결과는 명사 생성이름대기 과제를 범주에 따라 나 누어 분석한 기존의 연구 결과와 일치하였다(Cunje et al., 2007). Cunje 등(2007)은 정상 노년층 집단과 $\mathrm{MCI}$ 집단에게 생물성(동물, 채소/과일) 및 무생물성(도시/마을, 성) 범주의 생성이름대기 과제 를 실시하고 수행력을 비교하였는데, 그 결과 두 집단 간 생물성 유 무에 따른 수행력에는 유의한 차이가 나타나지 않았다고 하였다. Price 등(2012)은 정상 노년층과 기억형 MCI 집단을 대상으로 생 물성(동물) 및 무생물성(가게물건) 범주 생성이름대기 과제를 실시 하고 수행력을 분석한 결과, 두 집단 모두 무생물성 범주에서 높은 수행력을 보여, 범주의 생물성 유무는 정상 노년층으로부터 $\mathrm{MCI}$ 집단을 변별해주지 못한다고 하였다. 국내에서도 범주의 생물성 유 무에 따른 생성이름대기 과제 수행력의 차이를 분석한 시도가 있 었는데, Choi (2010)는 AD 집단을 대상으로 명사 생성이름대기 과 제를 생물성(동물, 과일)과 무생물성(탈 것, 의류) 범주로 나누어 실 시하고, 정상 노년층 집단과 수행력 차이를 비교하였다. 그 결과, 정 상 노년층은 생물성 범주에서 수행력이 유의하게 높았던 반면, $\mathrm{AD}$ 집단은 두 범주 간 수행력의 차이를 보이지 않아, $\mathrm{AD}$ 집단이 상대 적으로 생물성 범주에서 특정적 결함을 보인다고 하였다. 또한 $\mathrm{AD}$ 집단이 보이는 생물성 범주의 특정적 결함은 내측 측두엽(medial temporal lobe)의 위축과 관련 있는 반면, 무생물성 범주는 기능적 인 측면에서의 의미 지식이 요구되는 범주로, 전두-두정엽(frontotemporal lobe) 및 실비안구 주변(perisylvian)의 국소적 손상과 관 련 있다고 하였다(Choi, 2008; Gainotti, 2000). AD 집단은 MCI 집 단에 비해 임상학적으로 인지-언어 장애가 진행된 단계이고, 뇌의 위축(atrophy)이 나타나기 때문에, 생물성 유무에 따른 수행력에 영향을 미칠 가능성이 있다. 하지만 본 연구에서는 $\mathrm{MCI}$ 집단의 뇌 손상 기전을 확인할 수는 없었지만, 진단적 측면에서 $\mathrm{AD}$ 집단이 보 이는 생물성 유무에 따른 차별적 손상이 나타나지 않았다. 즉, $\mathrm{MCI}$ 집단은 정상 노화와 $\mathrm{AD}$ 의 중간 단계로, 인지-언어 및 뇌 손상이 $\mathrm{AD}$ 만큼 진행되지 않았기 때문에, 범주의 생물성 유무가 민감한 척도로 적용되기에는 한계가 있는 것으로 생각된다. 즉, 생물성 유 무에 따른 명사 생성이름대기 과제는 정상 노화과정으로부터 $\mathrm{AD}$ 를 변별해주는 매우 유용한 과제일 수 있지만(Albert, Moss, Tanzi, \& Jones, 2001; Choi 2008), MCI 집단을 정상 노년층으로부터 감별 진단하기에는 민감도가 떨어질 수 있다는 측면에서 유의할 필요가 있다.

마지막으로 본 연구에서는 동사 생성이름대기 과제를 실시하고, 정상 노년층 집단과 $\mathrm{MCI}$ 집단에서 어떠한 차이를 보이는지 살펴보 고자 하였다. 동사를 통사적 기준으로 세분화하여 자동사, 타동사, '-하다' 동사로 분류하여 비교하였다. 그 결과, 타동사에서 집단 간
차이가 통계적으로 유의하였는데, $\mathrm{MCI}$ 집단이 정상 노년층 집단 에 비해 타동사 산출에 어려움을 보이는 것으로 나타났다. 그러나 자동사와 '-하다' 동사에서는 두 집단 간 유의한 차이를 보이지 않 았다. 일반적으로 타동사는 문장을 완성하기 위해 2 개의 논항 구조 가 필요하기 때문에, 1 개의 논항만 필요한 자동사에 비해 통사적으 로 복잡하여 더 어렵다(Lee \& Thompson, 2004; Thompson, 2003). 그리고 통사적으로 복잡한 동사는 처리 과정에서도 차이를 보이는 데, 논항 개수가 더 많은 타동사는 자동사에 비해 두정엽(parietal lobe) 후반부 영역이 활성화된다(Thompson et al., 2007). 본 연구 결과는 타동사에서 $\mathrm{MCI}$ 집단이 저조한 수행력을 보였는데, 이는 통사적으로 더 복잡한 동사가 정상 노화 과정에서 $\mathrm{MCI}$ 집단을 민 감하게 변별해낼 수 있다는 기존 연구 결과와 일치한다(Östberg et al., 2005; Woods et al., 2005). 동사는 명사에 비해 문법적 요소가 강하고, 논항 구조를 생성해야 하는 인지적 부담(load)이 가해진다. 그러므로 전반적 인지 저하와 인지적 용량(capacity)이 제한된 $\mathrm{MCI}$ 집단의 경우에는 통사적으로 복잡할수록 결함을 보이는 것 으로 해석된다. 따라서 명사 생물성 기제보다는 동사가 가진 통사 적 특징이 $\mathrm{MCI}$ 집단을 더 민감하게 감별할 수 있는 언어적 특징일 수 있다. 또한 한국어는 동사가 문장 마지막에 위치하는 특징을 가 진 언어로 문장 내에서 동사를 산출하기 전, 동사와 관련된 논항을 우선적으로 활성화하여야 한다. 즉, 우리말은 동사에 선행하는 의 미적 단위(semantic unit)를 활성화한 후, 동사가 산출되는 'SOV' 구조를 가진 언어이다. 자동사와 비교하였을 때, 타동사는 동사에 선행되는 의미 단위가 더 많기 때문에 이러한 의미 단위의 활성화 에 문제가 발생할 경우 산출에 어려움이 생길 수 있다. 그러므로 $\mathrm{MCI}$ 집단이 타동사에서 보이는 선택적 결함은 $\mathrm{MCI}$ 집단이 동사 와 관련된 의미 단위에 접근하는 능력이 정상 노년층 집단에 비해 제한적일 때 발생할수 있다.

또 한 가지 살펴볼 수 있는 측면으로는 자동사와 타동사가 서술 어로 사용되는 문장 형태의 빈도이다. No (1999)는 한국어 교재 개 발을 위하여 문어(신문기사, 소설, 수필, 교과서)와 구어 자료(대화, 만화, 드라마)의 약 3,700 개의 문장에 대한 문형 분석을 하였는데, 그 결과 자동사가 서술어로 사용된 기본 문형은 13 개인 반면, 타동 사는 8개로 더 제한된 문형 수를 보였다. 하지만 한국어의 특징인 논항 생략 현상을 포함한 문형과 논항 구성이 완전한 문형을 추가 할 경우, 자동사 30 개, 타동사 31 개의 문형을 가져 유사한 빈도를 보 인다고 하였다. 이처럼 자동사와 타동사는 그 빈도에 큰 차이를 보 이지 않지만, 본 연구의 결과처럼 생성이름대기 과제에서 $\mathrm{MCI}$ 집 단이 타동사에서 유의한 결함을 보이는 것은 매우 의미 있는 결과 라고 할 수 있다. 이러한 결과들을 볼 때, 동사 생성이름대기 과제를 
수행하고 이를 세분화하여 동사를 유형별로 분석하는 것은 $\mathrm{MCI}$ 집단을 정상 노화 과정에서 감별해낼 수 있는 매우 중요한 방법임 을 제안한다.

본 연구는 정상 노년층 집단과 $\mathrm{MCI}$ 집단을 대상으로 명사 및 동 사생성이름대기 과제를 실시하여 그 수행력을 비교하였다는 데 큰 의의가 있다. 또한 동사 생성이름대기 과제를 실시한 후, 국내에서 는 시도되지 않았던 논항에 따른 동사 유형별 분석법을 통해, 특정 동사 유형에서 $\mathrm{MCI}$ 집단이 정상 노년층 집단과 구분되는 감별이 가능함을 도출했다.

그러나 동사는 논항과 같은 통사적 요소뿐만 아니라, 동사가 가 진 의미적(semantic) 요소에 의해서도 세분화 할 수 있을 것이다. 그 러므로 향후 연구에서는 동사가 가진 의미적 특성에 따라 세부적 으로 분석하여 두 집단 간 차이를 살펴볼 필요가 있다. 또한 생성이 름대기 과제의 경우, 관련된 다양한 인지적 기능을 밝히기 위해 산 출한 단어의 정반응 수뿐 아니라, 군집(clustering)과 전환(switching)이라는 처리 과정의 질적 측면의 분석이 중요하다(Troyer, Moscovitch, \& Winocur, 1997). 그러므로 추후 연구에서는 정상 노년 층과 $\mathrm{MCI}$ 를 대상으로 동사 생성이름대기 내에서의 군집의 수, 군 집의 크기, 전환의 수 등의 질적인 차이의 분석이 이루어져야 할 것 이다.

마지막으로 본 연구는 기억형 $\mathrm{MCI}$ 집단만을 대상으로 실시되었 기 때문에, 향후 비기억형 $\mathrm{MCI}$ 를 대상으로 동사 생성이름대기 과 제를 실시하여 동사 수행력이 $\mathrm{MCI}$ 의 아형 구분에 영향을 미칠 수 있는 지 살펴볼 필요가 있겠다.

\section{REFERENCES}

Albert, M. S., Moss, M. B., Tanzi, R., \& Jones, K. (2001). Preclinical prediction of $\mathrm{AD}$ using neuropsychological tests. Journal of the International Neuropsychological Society, 7(5), 631-639.

Alegret, M., Peretó, M., Pérez, A., Valero, S., Espinosa, A., Ortega, G., ... \& Rodríguez-Gómez, O. (2018). The Role of verb fluency in the detection of early cognitive impairment in Alzheimer's disease. Journal of Alzheimer's Disease, 62(2), 611-619.

Barde, L. H., Schwartz, M. F., \& Boronat, C. B. (2006). Semantic weight and verb retrieval in aphasia. Brain and Language, 97(3), 266-278.

Baldo, J. V., \& Shimamura, A. P. (1998). Letter and category fluency in patients with frontal lobe lesions. Neuropsychology, 12(2), 259.

Berndt, R. S., Haendiges, A. N., Mitchum, C. C., \& Sandson, J. (1997). Verb retrieval in aphasia. 2. Relationship to sentence processing. Brain and Lan- guage, 56(1), 107-137.

Bird, H., Ralph, M. A. L., Patterson, K., \& Hodges, J. R. (2000). The rise and fall of frequency and imageability: Noun and verb production in semantic dementia. Brain and Language, 73(1), 17-49.

Brucki, S. M. D., \& Rocha, M. S. G. (2004). Category fluency test: effects of age, gender and education on total scores, clustering and switching in Brazilian Portuguese-speaking subjects. Brazilian Journal of Medical and Biological Research, 37(12), 1771-1777.

Bushell, C. M., \& Martin, A. (1997). Automatic semantic priming of nouns and verbs in patients with Alzheimer's disease. Neuropsychologia, 35(8), 1059-1067.

Cappa, S. F., Binetti, G., Pezzini, A., Padovani, A., Rozzini, L., \& Trabucchi, M. (1998). Object and action naming in Alzheimer's disease and frontotemporal dementia. Neurology, 50(2), 351-355.

Choi, E., Sung, J. E., Jeong, J. H., \& Kwag, E. (2013). Noun-verb dissociation in a confrontation naming task for persons with mild cognitive impairment. Dementia and Neurocognitive Disorders, 12(2), 41-46.

Choi, H. J. (2008). A comparison of the performances of confrontation naming test and verbal fluency task in patients with prodromal Alzheimer's disease and mild Alzheimer's disease. Speech Sciences, 15(2), 111-118.

Choi, H. (2010). Category-specific impairment of patients with dementia of Alzheimer's type in category fluency tasks. Korean Journal of Communication \& Disorders, 15(4), 572-580.

Choi, H. (2011). Detecting language deficits in patients with mild cognitive impairment through verbal fluency and picture description tasks. Korean Journal of Communication \& Disorders, 16(2), 171-184.

Choi, H. (2012). Performances of verbal fluency task in normal elderly: effects of gender and educational level by categories. Journal of Speech \& Hearing Disorders, 21(21), 37-52.

Choi, H., Lee, J. Y., Choi, H., \& Lee, J. Y. (2017). Relationship to ratio of correct information unit and cognitive functions in patients with amnestic MCI and EAD. Communication Sciences \& Disorders, 22(3), 550-560.

Christensen, K. J., Multhaup, K. S., Nordstrom, S., \& Voss, K. (1991). A cognitive battery for dementia: development and measurement characteristics. Psychological Assessment: A Journal of Consulting and Clinical Psychology, 3(2), 168.

Clark, D. G., Wadley, V. G., Kapur, P., DeRamus, T. P., Singletary, B., Nicholas, A. P., ... \& Deutsch, G. (2014). Lexical factors and cerebral regions influencing verbal fluency performance in MCI. Neuropsychologia, 54, 98-111. Crepaldi, D., Aggujaro, S., Arduino, L. S., Zonca, G., Ghirardi, G., Inzaghi, M. 
G., ... \& Luzzatti, C. (2006). Noun-verb dissociation in aphasia: the role of imageability and functional locus of the lesion. Neuropsychologia, 44(1), 73-89.

Cunje, A., Molloy, D. W., Standish, T. I., \& Lewis, D. L. (2007). Alternate forms of logical memory and verbal fluency tasks for repeated testing in early cognitive changes. International psychogeriatrics, 19(1), 65-75.

Druks, J. (2002). Verbs and nouns-a review of the literature. Journal of Neurolinguistics, 15(3-5), 289-315.

Druks, J., Masterson, J., Kopelman, M., Clare, L., Rose, A., \& Rai, G. (2006). Is action naming better preserved (than object naming) in Alzheimer's disease and why should we ask?. Brain and Language, 98(3), 332-340.

Gainotti, G. (2000). What the locus of brain lesion tells us about the nature of the cognitive defect underlying category-specific disorders: a review. Cortex, 36(4), 539-559.

Gleitman, L. R. (1994). Words, words, words. Philosophical Transactions of the Royal Society of London. Series B: Biological Sciences, 346(1315), 7177.

Hsieh, S., Schubert, S., Hoon, C., Mioshi, E., \& Hodges, J. R. (2013). Validation of the Addenbrooke's Cognitive Examination III in frontotemporal dementia and Alzheimer's disease. Dementia and Geriatric Cognitive Disorders, 36(3-4), 242-250.

Hugues, C. P., Berg, L., Danzinger, W. L., Coben, L. A., \& Martin, R. L. (1982). A new clinical scale for the staging of dementia. British Journal of Psychiatry, 140, 566-572.

Hyun, J. M., Kim, H. H., Shin, J. C., \& Seo, S. G. (2003). Retrieval of nouns and verbs in Broca's and Wernicke's aphasia. Korean Journal of Communication \& Disorders, 8(3), 171-187.

Jack, C. R., Bennett, D. A., Blennow, K., Carrillo, M. C., Dunn, B., Haeberlein, S. B., ... \& Liu, E. (2018). NIA-AA Research Framework: Toward a biological definition of Alzheimer's disease. Alzheimer's \& Dementia, 14(4), 535-562.

Jung, I. K., Kwak, D. I., Joe, S. H., \& Lee, H. S. (1997). A study of standardization of Korean form of geriatric depression scale (KGDS). Journal of Korean Geriatric Psychiatry, 1(1), 61-72.

Kang, Y. W., Chin, J. H., Na, D. L., Lee, J. H., \& Park, J. S. (2000). A normative study of the Korean version of Controlled Oral Word Association Test (COWAT) in the elderly. Korean Journal of Clinical Psychology 19(2), 385392

Kang, Y. (2006). A normative study of the Korean-Mini Mental State Examination (K-MMSE) in the elderly. Korean Journal of Psychology: General,
25(2), 1-12.

Kang, Y. U., Jang, S. M., \& Na, D. L. (2012). Seoul Neuropsychological Screening Battery (SNSB-II), Seoul: Human Brain Research \& Consulting Co.

Kim, J. W. (2017). Performance of verb naming according to the aging process in Korean. Journal of Speech \& Hearing Disorders, 26(4), 11-19.

Kim, M., \& Thompson, C. K. (2000). Patterns of comprehension and production of nouns and verbs in agrammatism: implication for lexical organization. Brain and Language, 74(1), 1-25.

Kim, S. Y. (2003). Clinical characteristics of mild cognitive impairment. Dement Neurocognitive Disorders, 2(2), 96-100.

Kim, S. R., Park, C. I., Kim, D. Y., \& Hwang, M. A. (2004). Production of nouns and verbs in adults with Broca's aphasia: comparison between naming and narration. Korean Journal of Communication \& Disorders, 9(2), 1-18.

Lautenschlager, N. T., Riemenschneider, M., Drzezga, A., \& Kurz, A. F. (2001). Primary degenerative mild cognitive impairment: study population, clinical, brain imaging and biochemical findings. Dementia and geriatric cognitive disorders, 12(6), 379-386.

Lee, M., \& Thompson, C. K. (2004). Agrammatic aphasic production and comprehension of unaccusative verbs in sentence context. Journal of Neurolinguistics, 17, 315-330.

Lee, S. J., (2009). The characteristics of old age preparation of Korean adults and policy implications. In Health-Welfare Policy Forum, 1, 72-80.

Lee, Y. A. (2013). Characteristics of noun and verb generative naming of Korean community-dwelling elderly. (Master's thesis), Yonsei University, Seoul, Korea

Lim, J. S., Kim, J. E., Baek, M., Park, S. H., \& Kim, S. Y. (2005). Subtypes and their clinical characteristics of mild cognitive impairment (MCI): cross sectional study. Journal of the Korean Neurological Assocciation, 23(3), 348355.

Luzzatti, C., \& Chierchia, G. (2002). On the nature of selective deficits involving nouns and verbs. Italian Journal of Linguistics, 14(1), 43-72.

Monsch, A. U., Bondi, M. W., Butters, N., Salmon, D. P., Katzman, R., \& Thal, L. J. (1992). Comparisons of verbal fluency tasks in the detection of dementia of the Alzheimer type. Archives of neurology, 49(12), 1253-1258.

No, E. H. (1999). Study of sentence pattern frequency of Korean language for developing Korean textbooks. Journal of Korean Language and Literature Education, 6(1), 283-298.

Östberg, P., Fernaeus, S. E., Hellström, Å., Bogdanović, N., \& Wahlund, L. O. (2005). Impaired verb fluency: A sign of mild cognitive impairment. Brain and Language, 95(2), 273-279. 
Östberg, P., Crinelli, R. M., Danielsson, R., Wahlund, L. O., Bogdanovic, N., \& Fernaeus, S. E. (2007). A temporal lobe factor in verb fluency. Cortex, 43(5), 607-615.

Park, M., Sung, M. R., Kim, S. K., \& Lee, D. Y. (2014). Comparison of demographic characteristics, comorbidity, and health habits of older adults with mild cognitive impairment and older adults with normal cognitive function. Journal of Korean Academy of Nursing, 44(4), 351-360.

Petersen, R. C., Smith, G. E., Waring, S. C., Ivnik, R. J., Tangalos, E. G., \& Kokmen, E. (1999). Mild cognitive impairment: clinical characterization and outcome. Archives of Neurology, 56(3), 303-308.

Petersen, R. C., Doody, R., Kurz, A., Mohs, R. C., Morris, J. C., Rabins, P. V., ... \& Winblad, B. (2001). Current concepts in mild cognitive impairment. Archives of Neurology, 58(12), 1985-1992.

Petersen, R. C. (2004). Mild cognitive impairment as a diagnostic entity. Journal of Internal Medicine, 256(3), 183-194.

Price, S. E., Kinsella, G. J., Ong, B., Storey, E., Mullaly, E., Phillips, M., ... \& Perre, D. (2012). Semantic verbal fluency strategies in amnestic mild cognitive impairment. Neuropsychology, 26(4), 490.

Pulvermüller, F., Mohr, B., \& Schleichert, H. (1999). Semantic or lexico-syntactic factors: what determines word-class specific activity in the human brain?. Neuroscience Letters, 275(2), 81-84.

Ramsay, C. B., Nicholas, M., Au, R., Obler, L. K., \& Albert, M. L. (1999). Verb naming in normal aging. Applied Neuropsychology, 6(2), 57-67.

Rosen, W. G. (1980). Verbal fluency in aging and dementia. Journal of Clinical and Experimental Neuropsychology, 2(2), 135-146.

Ruff, R. M., Light, R. H., Parker, S. B., \& Levin, H. S. (1997). The psychological construct of word fluency. Brain and Language, 57(3), 394-405.

Shin, K. R., Kang, Y. H., Jung, D. Y., Kim, M. Y., Kim, J. S., Kim, M. J., \& Kim, M. J. (2011). Prevalence and characteristics of mild cognitive impairment in the community-dwelling elderly compared to elderly with normal cognitive function. Korean Journal of Adult Nursing, 23(1), 40-49.

Stokholm, J., Jørgensen, K., \& Vogel, A. (2013). Performances on five verbal fluency tests in a healthy, elderly Danish sample. Aging, Neuropsychology, and Cognition, 20(1), 22-33.

Sung, J. E., \& Kwag, E. J. (2012). Age-related verb naming abilities depending on the argument structures. Korean Journal of Communication \& Disorders, 17(4), 550-564.

Sung, J. E. (2016). The effects of verb argument complexity on verb production in persons with aphasia: evidence from a subject-object-verb language. Journal of Psycholinguistic Research, 45(2), 287-305.

Sung, J. E., DeDe, G., \& Lee, S. E. (2016). Cross-linguistic differences in a picture-description task between Korean-and English-speaking individuals with aphasia. American Journal of Speech-language Pathology, 25(4S), S813S822.

Thompson, C. K. (2003). Unaccusative verb production in agrammatic aphasia: the argument structure complexity hypothesis. Journal of Neurolinguistics, 16(2-3), 151-167.

Thompson, C. K., Bonakdarpour, B., Fix, S. C., Blumenfeld, H. K., Parrish, T. B., Gitelman, D. R., \& Mesulam, M. M. (2007). Neural correlates of verb argument structure processing. Journal of Cognitive Neuroscience, 19(11), 1753-1767.

Tierney, M. C., Yao, C., Kiss, A., \& McDowell, I. (2005). Neuropsychological tests accurately predict incident Alzheimer disease after 5 and 10 years. Neurology, 64(11), 1853-1859.

Troyer, A. K., Moscovitch, M., \& Winocur, G. (1997). Clustering and switching as two components of verbal fluency: evidence from younger and older healthy adults. Neuropsychology, 11(1), 138-146.

Won, C. W., Yang, K. Y., Rho, Y. G., Kim, S. Y., Lee, E. J., Yoon, J. L., ... \& Yoon, D. K. (2002). The development of Korean activities of daily living (K-ADL) and Korean instrumental activities of daily living (K-IADL) scale. Journal of the Korean Geriatrics Society, 6(2), 107-120.

Woods, S. P., Scott, J., Sires, D. A., Grant, I., Heaton, R. K., \& Tröster, A. I. (2005). Action (verb) fluency: test-retest reliability, normative standards, and construct validity. Journal of the International Neuropsychological Society, 11(4), 408-415. 


\section{국문초록}

\section{경도인지장애군과 정상 노년층의 명사 및 동사 유형에 따른 생성이름대기 수행력 비교}

최수진' · 성지은

${ }^{1}$ 이화여자대학원 언어병리학과, ${ }^{2}$ 이화여자대학교 목동병원 신경과, ${ }^{3}$ 이화여자대학교 의학과

배경 및 목적: 경도인지장애군은 기억력 저하와 함께 단어 산출에 어려움을 보이는데, 명사 뿐만 아니라 동사 산출에도 결함을 보인다. 본 연구는 경도인지장애 집단을 대상으로 품사에 따른 생성이름대기 과제를 실시하고 수행력 차이를 비교하였다. 방법: 본 연구는 경도 인지장애 집단 15 명과 정상 노년층 집단 15 명을 대상으로 품사(명사 vs. 동사)에 따른 생성이름대기 과제를 실시하였다. 명사 생성이름 대기 과제는 생물성 유무에 따라 두 개의 범주로 분류하였고, 동사 생성이름대기 과제는 산출된 동사를 세 가지 유형에 따라 분류하여 수행력 차이를 비교하였다. 결과: 경도인지장애 집단이 정상 노년층 집단에 비해 품사에 따른 생생이름대기 과제에서 유의하게 낮은수 행력을 보였다. 또한 두 집단 모두 동사 생성이름대기 과제에서 어려움을 보이는 것으로 나타났다. 명사 생성이름대기 과제에서는 범주 의 생물성 유무에 따른 수행력이 차이가 나타나지 않았다. 그러나 동사 생성이름대기 과제에서는 경도인지장애 집단이 정상 노년층에 비해 타동사의 산출에서 유의한 결함을 보이는 것으로 나타났다. 논의 및 결론: 동사 생성이름대기 과제는 정상 노화 과정으로부터 경 도인지장애군을 감별 진단하는 민감한 도구일 수 있다. 또한 동사를 유형에 따라 세부적으로 분석하는 것은 경도인지장애 집단의 선택 적 결함을 확인할 수 있는 매우 의미 있는 방법임을 제언한다.

핵심어: 경도인지장애, 생성이름대기 과제, 동사 유형, 명사 생물성

본 연구는 2019년도 산업통상자원부 및 산업기술평가관리원(KEIT) 연구비 지원에 의한 연구임('10077553').

\section{참고문헌}

강연욱, 진주희, 나덕렬, 이정희, 박재설(2000). 통제 단어 연상 검사 (Controlled Oral Word Association Test) 의 노인 규준 연구. 한국심리학회, 19(2), 385-392.

강연욱(2006). K-MMSE (Korean-Mini Mental State Examination)의 노인 규준 연구. 한국심리학회지: 일반, 25(2), 1-12.

강연욱, 장승민, 나덕렬(2012). 서울신경심리검사 2판. 서울: 휴브알엔씨.

김상윤(2003). 경도인지장애의 임상소견. 대한치매학회지, 2(2), 96-100.

김수련, 박창일, 김덕용, 황민아(2004). 브로카 실어증 환자의 과제간 명사와 동사의 산출 비교. 언어청각장애연구, 9(2), 1-18.

김정완(2017). 정상 성인의 노화과정에 따른 동사이름대기 능력. 언어치료연구, 26(4), 11-19.

노은희(1999). 한국어 교재 개발을 위한 한국어의 문형 빈도 조사. 국어교육연구, 6(1), 283-298.

박명화, 성미라, 김선경, 이동영(2014). 경도인지장애노인과 정상노인의 인구학적 특성, 동반질환 및 건강습관 비교. 대한간호학회지, 44(4), 351-360. 성지은, 곽은정(2012). 연령 및 동사 논항 구조에 따른 애니메이션을 활용한 동사 이름대기 과제 수행력 차이. 언어청각장애연구, 17(4), 550-564. 신경림, 강윤희, 정덕유, 김미영, 김정수, 김미정, 김민정(2011). 지역사회 거주 경도인지장애 노인의 유병율과 정상 노인과의 비교연구. 성인간호학회지, 23(1), 40-49.

원장원, 양금열, 노용균, 김수영, 이은주, 윤종률, ... 윤도경(2002). 한국형 일상생활활동 측정도구 (K-ADL) 와 한국형 도구적 일상생활활동 측정도구

(K-IADL) 의 특징. 대한노인병학회지, 6(1), 1-10.

이소정(2009). 우리나라 중장년층의 노후준비에 관한 인식과 정책적 함의. 보건복지포럼, 1,72-80.

이윤아(2013). 일반 노년층의 명사 및 동작동사생성이름대기 특성. 연세대학교 대학원 석사학위논문.

임준성, 김정은, 백민재, 박성호, 김상윤(2005). 경도인지장애의 아형 분류와 임상 양상. 대한신경과학회지, 23(3), 348-355.

정인과, 곽동일, 조숙행, 이현수(1997). 한국형 노인우울검사 (Korean form of Geriatric Depression Scale; KGDS) 표준화 연구 노인정신의학, 1(1), 61-72. 
최은정, 성지은, 정지향, 곽은정(2013). 경도인지장애군의 명사 및 동사 하위유형에 따른 대면이름대기 산출 능력. 대한치매학회지, 12(2), 41-46. 최현주(2008). 노인성 알츠하이머병 위험군과 초기 알츠하이머병 환자의 이름대기와 구어유창성 능력의 비교. 음성과학, 15(2), 111-118. 최현주(2010). 경도 알츠하이머형 치매 환자의 범주유창성 과제에서의 범주특정적 손상 특징. 언어청각장애연구, 15(4), 572-580.

최현주(2011). 구어유창성과 그림설명과제를 통한 경도인지장애 (MCI) 환자의 언어손상 검출. 언어청각장애연구, 16(2), 171-184. 최현주(2012). 고령자의 구어유창성 과제 수행력: 범주별 성별 및 교육정도에 따른 차이. 언어치료연구, 21(2), 37-52. 현정문, 김향희, 신지철, 서상규 (2003). 베르니케실어증과 브로카실어증 환자들의 명사와 동사 인출 비교. 언어청각장애연구, 8(3), 171-187.

\section{ORCID}

최수진(제1저자, 박사과정 http://orcid.org/0000-0003-1158-5940); 성지은(교신저자, 교수 http://orcid.org/0000-0002-1734-0058); 정지향(공동저자, 교수 http://orcid.org/0000-0001-7945-6956) 